\title{
Developing a Method of Understanding Lubab al-Takwil fi Ma'ani al-Tanzil in Tafsir Nur al-Ihsan by Umar, M. S. Based on Genetic Approach
}

Mohd Sholeh Sheh Yusuff, Yusuf Haji-Othman, Wan Nazjmi Mohamed Fisol

To Link this Article: http://dx.doi.org/10.6007/IJARBSS/v11-i11/11563 DOI:10.6007/IJARBSS/v11-i11/11563

Received: 06 September 2021, Revised: 10 October 2021, Accepted: 30 October 2021

Published Online: 11 November 2021

In-Text Citation: (Yusuff et al., 2021)

To Cite this Article: Yusuff, M. S. S., Haji-Othman, Y., \& Fisol, W. N. M. (2021). Developing a Method of Understanding Lubab al-Takwil fi Ma'ani al-Tanzil in Tafsir Nur al-Ihsan by Umar, M. S. Based on Genetic Approach. International Journal of Academic Research in Business and Social Sciences, 11(11), 716-722.

Copyright: (c) 2021 The Author(s)

Published by Human Resource Management Academic Research Society (www.hrmars.com) This article is published under the Creative Commons Attribution (CC BY 4.0) license. Anyone may reproduce, distribute, translate and create derivative works of this article (for both commercial and non-commercial purposes), subject to full attribution to the original publication and authors. The full terms of this license may be seen at: http://creativecommons.org/licences/by/4.0/legalcode

Vol. 11, No. 11, 2021, Pg. $716-722$

Full Terms \& Conditions of access and use can be found at http://hrmars.com/index.php/pages/detail/publication-ethics 


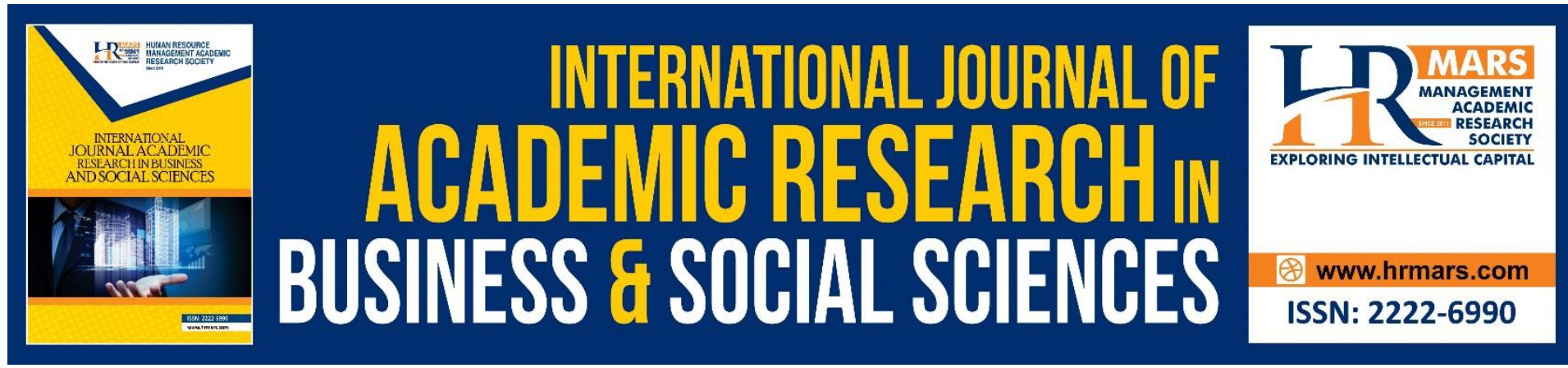

\title{
Developing a Method of Understanding Lubab al- Takwil fi Ma'ani al-Tanzil in Tafsir Nur al-Ihsan by Umar, M. S. Based on Genetic Approach
}

\author{
Mohd Sholeh Sheh Yusuff, Yusuf Haji-Othman, Wan Nazjmi \\ Mohamed Fisol \\ Sultan Abdul Halim Mua'dzam Shah International Islamic University, Kuala Ketil, Kedah, \\ Malaysia
}

\begin{abstract}
Tafsir Nur al-Ihsan is a book in the field of Quranic exegesis written by Umar, M. S. The Muslim community has used this book as a reference to understand the meaning of the al-Quran. However, there is a tremendous amount of denunciation done towards the book by the community due to the lack of clear resources in translating verses of al-Quran, which has confused the community on the legality of the translation done in the book. Therefore, the main objective of this research is to study and detect the original resources of the writer in the Tafsir Nur al-Ihsan, and express how the sources are taken from the Quranic verses. The analysis of Tafsir Nur al-Ihsan used the genetic approach which Goldman publicized in studying the origin of the resources. While carrying out the research, the researcher referred to the text from Tafsir Nur al-Ihsan and Lubab al-Takwil fi Ma'ani al-Tanzil and compared both texts to detect the similarities and differences. The result of the analysis proved that Umar implemented five methods; the text was referenced from Lubab al-Takwil fi Ma'ani al-Tanzil while finishing his work which is quoting the text, writing an abstract, removal of some of the words, adding explanation, and refuting part of the text. The research showed that Umar refers to the Lubab al-Takwil fi Ma'ani al-Tanzil while creating his work to strengthen the translations written. Thus, he successfully strengthens translation when the contents of the text are parallel to the reference. However, in certain places existed a text from the Tafsir Nur al-Ihsan, which contradicts Lubab al-Takwil fi Ma'ani al-Tanzil's content, which failed to strengthen the translation in a particular part of the text. This study suggests that thorough research be done by the next researcher on all the works referred to by Sheikh Muhammad Said when writing Tafsir Nur al-Ihsan. This is to completely remove the public's doubts about this work.
\end{abstract}

Keywords: Tafsir Nur al-Ihsan, Lubab al-Takwil fi Ma'ani al-Tanzil, Genetic Approach, Comparison, Reference

Introduction

Tafsir Nur al-Ihsan is a tafsir of the Qur'an that is still used as a teaching and reference material until now, especially in institutions of learning, in mosques, and musollas. For example, weekly studies at Pondok Tuan Guru Haji Bakar Parit Panjang, Baling Kedah Malaysia and 
Pondok Tuan Guru Haji Soleh Musa in Sik Kedah Malaysia. However, the author of tafsir in his work does not clearly state the source of the quotation in interpreting the verses of the Qur'an. That has confused the public about the validity of the interpretation he has made (Zaim, 2010). The writing of this work has shortcomings because there is a lack of writing style that does not state the source of facts and weaknesses due to the author's use of many unfounded opinions in his interpretation (Zaim, 2010). The stories in this work are also dubious as the author does not describe the reference source in detail. Therefore, the community needs to be careful when reading and referring to this work (Taib, 2003).

Considering that Tafsir Nur al-Ihsan is still used as teaching material in the interpretation of the Qur'an and community reference in understanding the holy verses of the Qur'an, then the effort to purify this work should be done (Yusuff, 2020). One form of such effort is through studies that use a genetic approach that will reveal and find the origin of the data used by the author when writing Tafsir Nur al-Ihsan (Sohaimi, 2001). In conducting this research, the researchers applied the source study, one of the research methods in the genetic approach. Through this method, researchers will dissect and identify the source of the text referred to by Umar (1970) in producing Tafsir Nur al-Ihsan and revealing how the author processes the text referred to in his work (Sohaimi, 2001). Moreover, this research only focuses on the text from Lubab al-Takwil fi Ma'ani al-Tanzil referred to by Umar (1970) as an initial effort towards refining Tafsir Nur al-Ihsan and also as an example of the ability to apply genetic approaches to works in the field of tafsir al-Quran, which in turn can be expanded to other reference works, which will undoubtedly contribute towards the perfection of the work of Tafsir Nur alIhsan.

\section{Research Methodology}

In conducting this research, the researchers applied a genetic approach. Through a genetic approach, researchers examine and show the origin of a written work or how work has influenced the writing of another author's work (Sohaimi, 2001). For example, Tafsir Pimpinan al-Rahman by Basmeih (2000) has been influenced by Tafsir al-Tabari by Ibn Jarir (Basmeih, 2000), Tafsir Ibn Kathir by Ibn Kathir (Basmeih, 2000) and Ruh al-Ma'ani by al-Alusi (Basmeih, 2000). Initially, an author writes his or her work after reading, researching, and understanding the text of a work that has caught his or her attention either consciously or unconsciously (Ronidin, 2011). The author processes the text from the books he reads and then he transfers the text into his work (Ronidin, 2011).

The word genetic comes from the root word "gene", and in Greek, genea means breed, kind and Gene means seed (Sinar, 2003). This genetic approach is a study of the relationship between works that show similarities based on seed or origin factors (Sinar, 2003). Another word related to it is genesis, which encompasses the origin, production, and creation (Sinar, 2003). According to Ronidin (2011), the genetic approach is also known as the study of influence in a text. This approach is more accurately said to be a source study or an original study that discusses where exactly an influence comes from (Ronidin, 2011).

According to Lubis (1994), the genetic approach is divided into five aspects, namely influence, adaptation, plagiarism, imitation, and translation. Among the five aspects, the one that is rather difficult to separate is imitation and influence (Lubis, 1994). This is due to judging a work whether it imitates or has been influenced by other works is only known by the author of the work itself 
because what can distinguish between imitation and influence is the element that involves intentional and unintentional acts (Lubis, 1994). This means when the author makes an imitation; he does so intentionally and consciously. Conversely, influence occurs when the author does so unintentionally. However, it is very rare for an author to admit that his writing is through imitation or influence (Lubis, 1994). Shaw (1990) states:

"A writer can be said to be influenced by another writer when evidence from outside can be made the material of a sufficiently convincing study. In contrast to imitation, the work of the affected author is recognized as his. Influence is something very broad happening anywhere and anytime".

Through the study of sources, the researchers analyzed the original text of Lubab al-Takwil fi Ma'ani al-Tanzil used by Umar (1970) in producing a work entitled Tafsir Nur al-Ihsan. When researchers want to find the original text for the work of Tafsir Nur al-Ihsan, the research process ensures that researchers make a comparison between Tafsir Nur al-Ihsan and Lubab al-Takwil fi Ma'ani al-Tanzil. This process of comparison is to find out the similarities and differences between the two texts. If the written text is in line with the referenced text, it reinforces the author's interpretations. But on the other hand, if the written text is different from the text from Lubab alTakwil fi Ma'ani al-Tanzil, this confuses the author's text.

\section{Discussion}

This research is conducted on five aspects in Tafsir Nur al-Ihsan, including The Contexts and Occasions of the Revelation of the Qur'an (Sabab Nuzul Ayah), hadiths (al-Hadith), the stories of Isra'iliyyat (al-Isra'iliyyat), The Abrogating and Abrogated Verses in the Qur'an (Nasikh and Mansukh) and The Text about Advantages (Fadhilat) (Umar, 1970). The researchers chose these five aspects because they are the primary debates of the author in the work (Umar, 1970). The list of texts on the five aspects includes 49 texts (42.9\%) on the Sabab Nuzul Ayah, 13 texts (11.4\%) of the al-Hadith, 49 texts (42.9\%) of al-Isra'aliyyat, 1 text (0.8\%) of al-Nasikh and al-Mansukh and 2 texts (1.7\%) on Fadhilat (Umar, 1970).

Umar (1970) has used five methods when transferring the text from Lubab al-Takwil fi Ma'ani al-Tanzil into Tafsir Nur al-Ihsan, namely quoting the text in parallel, quoting the text in the abstract, dropping some words found in the text of Lubab al-Takwil fi Ma'ani al-Tanzil, adding descriptions in the text that retrieved and changed part of the referenced text [26]. This is shown in Table 1.

Table 1: The way the author uses the text of Lubab al-Takwil fi Ma'ani al-Tanzil

\begin{tabular}{|c|c|c|c|c|c|c|c|c|}
\hline No. & Aspects & $\begin{array}{l}\text { Parall } \\
\text { el }\end{array}$ & $\begin{array}{l}\text { Abstrac } \\
t\end{array}$ & $\begin{array}{l}\text { Droppi } \\
\text { ng }\end{array}$ & $\begin{array}{l}\text { Addin } \\
g\end{array}$ & $\begin{array}{l}\text { changi } \\
\text { ng }\end{array}$ & $\begin{array}{l}\text { Tota } \\
\text { I }\end{array}$ & Percent \\
\hline 01 & $\begin{array}{l}\text { Sabab Nuzul } \\
\text { Ayah }\end{array}$ & 9 & 16 & 19 & 4 & 1 & 49 & 42.9 \\
\hline 02 & Al-Hadith & 1 & 6 & 6 & 0 & 0 & 13 & 11.4 \\
\hline 03 & Al-Isra'iliyyat & 3 & 23 & 19 & 3 & 1 & 49 & 42.9 \\
\hline 04 & Nasikh Mansukh & 0 & 1 & 0 & 0 & 0 & 1 & 0.8 \\
\hline \multirow[t]{3}{*}{05} & Fadhilat & 0 & 1 & 0 & 1 & 0 & 2 & 1.7 \\
\hline & Total & 13 & 47 & 44 & 8 & 2 & 114 & 100 \\
\hline & Percent & 11.4 & 41.2 & 38.5 & 7 & 1.7 & 100 & \\
\hline
\end{tabular}


Table 1 indicates that Umar (1970) has practiced five ways in using the text from Lubab alTakwil fi Ma'ani al-Tanzil, which is referred to when writing Tafsir Nur al-Ihsan. First, he quoted the text in parallel from Lubab al-Takwil fi Ma'ani al-Tanzil where the text written by him is the same as the original text from the text of Lubab al-Takwil fi Ma'ani al-Tanzil, i.e., 13 texts (11.4\%) including sabab nuzul ayat 9 of the texts, al-Hadith 1 text, and al-Isra'aliyyat 3 texts (Umar, 1970).

Second, the author quotes the meaning of the text contained in Lubab al-Takwil fi Ma'ani alTanzil and then he includes it in Tafsir Nur al-Ihsan (Umar, 1970). This second way means that when the author refers to Lubab al-Takwil fi Ma'ani al-Tanzil and understands its contents, he translates his understanding into his work through a new verse arrangement in his way. The resulting excerpt is in abstract form following the original work referred to. Only the meaning of the text is similar to each other, but the form of the text is different (Sohaimi, 2001). There are 47 texts (41.2\%) where the author refers to Lubab al-Takwil fi Ma'ani al-Tanzil in this second way, namely 16 texts on the sabab nuzul ayat, 6 texts of the al-Hadith, 23 texts of alIsra'iliyyat, 1 text of al-Nasikh and al-Mansukh, and 1 text about fadhilat (Umar, 1970).

Third, the author omits certain verses or sentences from Lubab al-Takwil fi Ma'ani al-Tanzil after he quotes the text from the work (Umar, 1970). He did so with texts that were too long to make it difficult for the public to understand. These abortions often involve data on alIsra'iliyyat that have various opinions and discussions of scholars about it or other deemed inappropriate opinions if loaded together. Therefore, the author selects only some opinions to be adapted in his work, and some other opinions are dropped. There are 44 texts (38.5\%) in which the author applies this third way, namely 19 texts sabab nuzul ayat, 6 texts of the alHadith, and 19 texts of al-Isra'iliyyat (Umar, 1970).

Fourth, the author expands the description of the referenced text to facilitate the community to refer to and understand the content of Tafsir Nur al-Ihsan (Umar, 1970). There are 8 texts (7\%) in which the author makes additions to the text taken from Lubab al-Takwil fi Ma'ani alTanzil, namely 4 texts sabab nuzul ayat, 3 texts of al-Isra'iliyyat, and 1 text on fadhilat (Umar, 1970).

The fifth is the last way that the author also does is to change the information of the text of Lubab al-Takwil fi Ma'ani al-Tanzil that is borrowed. The conversion made was not very noticeable, as it only involved a translation made of the original text. The study found that this conversion occurred because the author inadvertently made a translation error of the text of Lubab al-Takwil fi Ma'ani al-Tanzil referred to, and by itself, this latter method is applied (Umar, 1970). There are 2 texts in which the author has done this fifth way, namely 1 text of sabab nuzul ayat and 1 text of the al-Isra'iliyyat (Umar, 1970).

\section{Conclusion}

Based on the research and analysis that has been done, the study found that Umar (1970) has only one purpose when referring to the text from Lubab al-Takwil fi Ma'ani al-Tanzil; that is, he merely wishes to reinforce the interpretations and descriptions that have been made. Even so, the study also identified that the author obtained two results in realizing its purpose namely success and failure. 
The success of the author results when the text is written about an aspect, for example, the sabab nuzul ayah in Tafsir Nur al-Ihsan is in line with the text referred to from Lubab al-Takwil fi Ma'ani al-Tanzil, whether the equation fits the form of the text or the content of the text (Sohaimi, 2001). For example, the author refers to a text from Lubab al-Takwil fi Ma'ani alTanzil (al-Khazin, 1979);

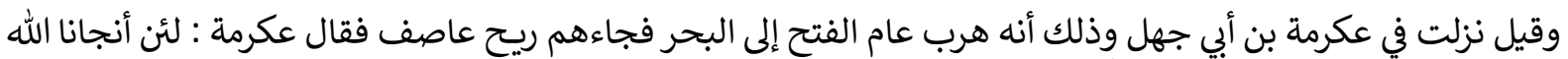

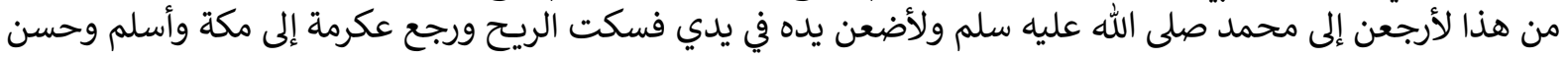
إسلامه.

While the text from Tafsir Nur al-Ihsan, the author writes, "it is narrated that the verse was revealed about Ikrimah ibn Abi Jahl that he fled on the day of the Conquest of Makkah and sailed to the sea, suddenly came a strong wind, then he said; if Allah saves us from this calamity surely I will return to Muhammad s.a.w and put my hand on his hand, then the wind stop. Ikrimah went straight to Mecca and embraced Islam and he was among the good Muslims (Umar, 1970)".

The two texts above explain the reason for the decline of the 32 nd verse, Surah Luqman tells the story of a companion of the Prophet SAW who was afflicted with calamity before he converted to Islam. At that time, he swore that if he escaped the catastrophe, he would be a follower of the Prophet SAW. The study found that the author had referred to the text from Lubab al-Takwil fi Ma'ani al-Tanzil and then included it in Tafsir Nur al-Ihsan in parallel without the slightest addition or subtraction of verses. The example proves that Umar (1970) has succeeded in strengthening the interpretation that has been made in Tafsir Nur al-Ihsan.

While the author fails to realize his purpose when the text is written is contrary to the text referred to (Sohaimi, 2001). This can be seen through the following example taken from Lubab al-Takwil fi Ma'ani al-Tanzil (al-Khazin, 1979);

$$
\text { وقتل مسيلمة ـ الكذاب في زمن خلافة أبي بكر الصديق قتله وحشي قاتل حمزة بن عبد المطلب. }
$$

While the author wrote, "Musaylamah was killed by Khalid ibn al-Walid (Umar, 1970),". The text explains the reason for the decline of the 93rd verse, Surah al-An'am which insults Musaymah because he claimed to be the Prophet after the Prophet SAW, then Musaimah was killed by the Muslim army. Through the text of Tafsir Nur al-Ihsan, the author states that the companion who killed Musaylamah was Khalid bin al-Walid compared to the original text which is the text of Lubab al-Takwil fi Ma'ani al-Tanzil which states that the person who killed Musaylamah was Hamzah bin Abd al-Muttalib. Such quotations and translations confuse the reader and the public and, at the same time, make the purpose and intention of the author in this section have failed.

Therefore, this article concludes that the genetic approach that has been applied in conducting this research is a comparative study approach in the field of literature. This approach is used to detect the influences that have influenced work by comparing one influence with another (Shaw, 1990). This approach involves three patterns, namely source study, mediator study, and acceptance study (Sohaimi, 2001). This study applies the analysis of sources in analyzing and identifying the original reference from Lubab al-Takwil fi Ma'ani 
al-Tanzil used by Umar (1970) when producing Tafsir Nur al-Ihsan, in addition to showing how Umar (1970) transferred the text referenced into his work.

Based on the analysis that has been made, Lubab al-Takwil fi Ma'ani al-Tanzil is used as a reference by Umar (1970) to the five aspects contained in Tafsir Nur al-Ihsan, namely sabab nuzul ayah represents 49 texts (42.9\%), 13 texts (11.4\%) al-Hadith, 49 texts (42.9\%) alIsra'aliyyat, 1 text (0.8\%) al-Nasikh and al-Mansukh, as well as 2 texts of fadhilat (1.7\%) (Umar, 1970).

Therefore, this article proves that Umar (1970), in producing this work entitled Tafsir Nur alIhsan did not use unfounded facts or use his own opinion in creating Tafsir Nur al-Ihsan, he has made Lubab al-Takwil fi Ma'ani al-Tanzil as one of the works that became his reference in interpreting the holy verses of the Quran.

\section{References}

Al-Khazin, M. DI. (1979) Lubab al-Takwil fi Ma'ani al-Tanzil. Beirut: Dar al-Fikr.

Basmeih, A. (2000) Tafsir Pimpinan al-Rahman Kepada Pengertian al-Qur'an. Cetakan ke-16. Kuala Lumpur: Dar al-Fikr.

Lubis, M. B. (1994) Pendekatan Genetik dalam Kesusasteraan Bandingan: Beberapa Pengantar Awal dalam Jaafar Husin (ed.), Pengantar Kesusasteraan Bandingan. Kuala Lumpur: Dewan Bahasa dan Pustaka.

Ronidin. (2011) Malin Kundang, Ibunya Durhaka. Lingua Didaktika, Volume 4 No 2, 114-125.

Shaw, J. T. (1990) "Keberhutangan Kesusasteraan dan Kajian Sastera Bandingan", dalam Newton P. Stallknecht dan Horst Frenz (ed.), Sastera Perbandingan: Kaedah dan Perspektif, Kuala Lumpu: Dewan Bahasa dan Pustaka.

Sinar, T. T. Z. (2003) Pancaran Filosofis Rabindranath Tagore dan Hinduisme pada Sanusi Pane: Satu Pendekatan Genetik. Studia Kultura, Nomor 3 Tahun 2, 211-228.

Sohaimi, A. Z. (2001) Kesusasteraan Bandingan: Perkembangan, Pendekatan Praktis. Kuala Lumpur: Utusan Publications \& Distributors Sdn. Bhd.

Taib, M. I. (2003) Israiliyyat Dalam Tafsir: Kajian Terhadap Kitab Nur al-Ihsan, Karya Haji Muhammad Said bin Umar. Disertasi Sarjana Pengajian Islam, Universiti Malaya.

Umar, M. S. (1391H/1970M) Tafsir Nur al-Ihsan. Fatani: Matba'ah Bin Halabi.

Yusuff, M. S. (2020) Bacaan Intertekstual Terhadap Tafsir Nur al-Ihsan: Kajian Menurut Kaedah Ekspansi, Jurnal Dunia Pengurusan, Vol. 2, No. 2, 1-11, 2020.

Zaim, M. N.(2010) Kajian Takhrij Hadith Dalam Tafsir Nur Al-Ihsan.Disertasi Sarjana Sastera, Universiti Sains Malaysia. 